\title{
Pengaruh Penerapan Pendekatan Realistic Mathematics Education terhadap Kemampuan Koneksi Matematika Siswa Madrasah Tsanawiyah Pondok Pesantren Darel Hikmah Pekanbaru
}

\author{
Hayatun Nufus, Suci Yuniati \\ Program Studi Pendidikan Matematika, Fakultas Tarbiyah dan \\ Keguruan, UIN Sultan Syarif Kasim Riau \\ Email: suciyuniati_mlg@yahoo.co.id
}

\begin{abstract}
ABSTRAK. Tujuan penelitian ini adalah untuk mengetahui apakah terdapat perbedaan antara kemampuan koneksi matematika siswa yang belajar menerapkan pendekatan Realistic Mathematics Education dengan siswa yang belajar tidak dengan pendekatan Realistic Mathematics Education.Metode penelitian yang digunakan adalah kuasi eksperimen desain non equvalent control group design. Sampel dalam penelitian ini sebanyak 2 kelas yaitu kelas Kelas VIIIB $_{2}$ sebagai kelas eksperimen dan kelas VIIIB $_{3}$ sebagai kelas kontrol. Pengumpulan data dilakukan dengan wawancara, observasi, dokumentasi dan tes. Berdasarkan data yang diperoleh dan dianalisis datanya normal dan homogen sehingga uji yang digunakan adalahu uji-t. Berdasarkan hasil analisis data diperoleh, dapat disimpulkan bahwa terdapat perbedaan antara kemampuan koneksi matematika siswa yang belajar menerapkan pendekatan Realistic Mathematics Education dengan siswa yang belajar tanpa menerapkan pendekatan Realistic Mathematics Education.

Kata Kunci : pendekatan realistic mathematics education, koneksi matematika
\end{abstract}




\section{PENDAHULUAN}

Kemampuan koneksi merupakan bagian dari kemampuan berfikir dalam matematika dan merupakan suatu hal yang penting dalam suatu pembelajaran. Kemampuan koneksi matematika mengacu kepada pemahaman yang mengharuskan siswa dapat mernperlihatkan hubungan antara topik dalam matematika, mengemukakan ide-ide dalam matematika, mencari hubungan yang representatif antara konsep dengan prosedur dan mengaitkan matematika dengan pelajaran lain serta dalam kehidupan seharihari. Tujuannya adalah agar pemikiran siswa menjadi luas, siswa akan mampu memahami konsep, siswa mengerti apa tujuan dari pembelajaran dan siswa mampu mengaplikasikan matematika dalam kehidupan.

Kemampuan koneksi dalam matematika sangat erat kaitannya dengan belajar matematika dalam kehidupan nyata. Menghubungkan suatu konsep dengan kehidupan sehari-hari sangat berperan penting, karena menjadikan suatu pembelajaran itu menjadi konkrit dan siswa mudah untuk mengingatnya. Hal ini diperkuat dengan adanya teori Bruner (Risnawati, 2008) dimana dalam proses belajar, siswa melewati tiga tahap yaitu:1) Enaktif: berkaitan dengan benda-benda kongkrit dalam belajar, 2) Iconic: menunjukkan pada gambar dan grafik, dan 3) Symbolik: menggunakan katakata dan simbol.

Berdasarkan hasil wawancara yang dilakukan pada 26 Mei 2014 dengan guru mata pelajaran matematika di MTs Pondok Pesantren Darel Hikmah Pekanbaru diketahui bahwa kesulitan yang dialami sebagian besar siswa adalah siswa tidak bisa menghubungkan materi matematika dalam kehidupan sehari-hari, sebagian siswa tidak bisa menghubungkan konsep matematika dengan konsep dalam pelajaran lain. Selain itu, siswa cenderung pasif sehingga guru kesulitan untuk menggali ide yang ada pada siswa tersebut.

Sejalan dengan permasalahan tersebut, guru tersebut telah berusaha untuk memberikan pengajaran dengan menggunakan metode pembelajaran seperti metode ceramah, tanya jawab, diberikan latihan soal dan lain-lain. Akan tetapi pembelajaran tersebut kurang efisien karena masih banyak siswa yang belum mampu menghubungkan suatu topik matematika, bahkan ada sebagian siswa yang mencontek dengan temannya ketika diberikan soal yang berkaitan dengan kehidupan nyata yang sifatnya menghubungkan. Keadaan ini menunjukkan aspek dari tujuan pembelajaran matematika terutama pada kemampuan koneksi matematika siswa masih rendah. Adapun gejala-gejala rendahnya kemampuan koneksi matematika siswa tersebut yaitu: 
a. siswa tidak bisa mengemukakan idenya.

b. siswa tidak bisa menghubungkan materi matematika sebelumnya dengan materi matematika yang dipelajari.

c. siswa tidak bisa menghubungkan konsep matematika dengan konsep dalam disiplin ilmu lain.

d. siswa tidak bisa mengaitkan (mengaplikasikan) matematika dalam kehidupan nyata.

e. siswa tidak bisa menyelesaikan soal yang berbentuk cerita.

Berdasarkan gejala-gejala yang ada, maka perlu dilakukan perbaikan dan pembaharuan dalam pembelajaran. Salah satu alternatif dalam perbaikan pembelajaran yang sesuai dengan gejala-gejala tersebut adalah dengan menerapkan pendekatan Realistic Mathematics Education.

Melalui pendekatan Realistic Mathematics Education, siswa harapkan dapat mengaitkan langsung apa yang ia alami dalam kehidupannya dengan kehidupan terapan yang terkandung dalam matematika, hal ini sesuai dengan pendapat Zulkardi (Tandililing,) bahwa teori Realistic Mathematics Education terdiri dari 5 karakteristik salah satu diantaranya yaitu penggunaan real konteks sebagai titik tolak dalam belajar metematika dan mengkaitkan berbagai topik dalam matematika. Jadi dengan menerapkan pendekatan Realistic Mathematics Education diharapkan mampu untuk membimbing siswa untuk menghubungkan konsep-konsep dalam matematika secara utuh.Hal ini sebagaimana diungkapkan Gravemeijer (Tarigan, 2006) bahwa dalam pembelajaran Realistic Mathematics Education suatu bahan matematika terkait dengan berbagai topik matematika secara integrasi (utuh).

\section{METODE PENELITIAN}

Penelitian ini merupakan penelitian quasi eksperimentataupenelitian semu. Penelitian ini adalah penerapan pendekatan Realistic Mathematics Education, sedangkan variabel yang dipengaruhi adalah kemampuan koneksi matematika siswa. Penelitian ini melibatkan dua kelas yaitu kelas eksperimen dan kelas kontrol yang dibandingkan. Kelas eksperimen memperoleh perlakuan dengan menerapkan pendekatan Realistic Mathematics Education, sedangkan kelas kontrol tidak akan mendapatkan perlakuan dalam artian bahwa pembelajaran dilaksanakan seperti biasa tanpa menerapkan pendekatan Realistic Mathematics Education.

Desain yang digunakan dalam penelitian ini adalah Non Equivalent Control Group Design. Pada desain ini kelas eksperimen maupun kelas kontrol dipilih acak, kemudian diberi pretest untuk mengetahui kemampuan 
awal siswa dan juga untuk mengetahui ada atau tidak ada perbedaan kemampuan awal antara kelompok eksperimen dan kelompok kontrol. Hasil pretest yang baik bila nilai kelompok eksperimen tidak berbeda secara signifikan. Selanjutnya pada tahap akhir, siswa diberikan soal postest. Data pada penelitian ini diperoleh dari hasil wawancara, observasi dan tes.

\section{HASIL PENELITIAN DAN PEMBAHASAN Hasil Penelitian}

Dalam penelitian ini, data yang dianalisis adalah kemampuan koneksi matematika siswa. Kemampuan koneksi matematika siswa dianalisis melalui data pretest sebelum diberi perlakuan dan data postest setelah diberikan perlakuan.

Setelah dilakukan uji pada pretest, diketahui bahwa data tidak terdapat perbedaan kemampuan awal koneksi matematika siswa antara kelas kontrol dan kelas eksperimen. Selanjutnya, hasil pengujian normalitas dan homogenitas terhadap postes diketahui bahwa postes di kedua kelas, baik kontrol maupun eksperimen berdistribusi normal dan homogen. Oleh karena itu, untuk menguji hipotesis pada penelitian ini digunakan uji-t. Berdasarkan hasil uji- $t$ diperoleh nilai $t_{\text {hitung }}=2,509$, sedangkan nilai $t_{\text {tabel }}$ dengan derajat kebebasan $(d k)=34+28-2=60$. Nilai $t_{\text {tabel}}$, pada taraf signifikan $5 \%$ dengan $\mathrm{dk}=60$ adalah 2,047 hal ini berarti bahwa $t_{\text {hitung }} \geq t_{\text {tabel }}$ atau $2,509 \geq 2,047$. Sehingga dapat ditarik kesimpulan bahwa $\mathrm{H}_{\mathrm{a}}$ diterima dan $\mathrm{H}_{0}$ ditolak yang berarti kesimpulan kemampuan akhir adalah "Ada perbedaan kemampuan koneksi matematika antara siswa yang belajar menerapkan pendekatan Realistic Mathematics Education dengan siswa yang belajar tidak menerapkan pendekatan Realistic Mathematic Education".

\section{Pembahasan}

Berdasarkan $t_{\text {hitung }}$ dan rata-rata yang diperoleh dari hasil analisis data tentang kemampuan koneksi matematika siswa pada pokok bahasan Lingkaran di MTs Pondok Pesantren Darel Hikmah Pekanbaru terlihat bahwa rata-rata kemampuan koneksi matematika siswa kelas eksperimen yang menerapkan pendekatan Realistic Mathematics Education adalah 67,96 lebih tinggi daripada rata-rata kemampuan koneksi matematika siswa kelas kontrol yang tidak menerapkan pendekatan Realistic Mathematics Education yaitu 57,12 .

Perbedaan yang terjadi menunjukkan adanya pengaruh positif penerapan pendekatan Realistic Mathematics Education terhadap kemampuan koneksi matematika siswa dibandingkan kelas yang tidak 
menerapkan pendekatan Realistic Mathematics Education. Selain itu, dilihat dari jawaban siswa dapat dikatakan bahwa kemampuan koneksi matematika siswa eksperimen lebih baik dibandingkan dengan kemampuan koneksi matematika di kelas kontrol. Hal itu terlihat jika di kelas eksperimen walaupun jawaban akhir salah akan tetapi siswa rata-rata bisa menghubungkan setiap jawabannya, akan tetapi hal tersebut berbeda di kelas kontrol, dengan melihat perbedaan tersebut dapat dikatakan bahwa pendekatan Realistic Mathematics Education memiliki pengaruh yang positif terhadap kemampuan koneksi matematika siswa.

Hal ini senada dengan pendapat sugiyono bahwa jika kelompok treatment lebih baik dari pada kelompok kontrol maka perlakuan yang diberikan berpengaruh positif (Sugiyono, 2010). Selain itu, pembelajaran matematika dengan pendekatan Realistic Mathematics Education atau PMR menjadikan pelajaran matematika manjdi lebih bermakna bagi siswa (Hadi, 2005).Di samping itu, denganmempelajari materi matematika secara nyata siswa mampu dengan mudah untuk menghubungkan materi tersebut dan pembelajaran akan lama untuk diingat karena siswa tahu kegunaan secara nyata apa yang dipelajarinya.

Dengan demikian hasil analisis ini mendukung rumusan masalah yang diajukan yaitu ada perbedaan kemampuan koneksi matematika siswa yang belajar menerapkan pendekatan Realistic Mathematics Educationdengan kemampuan koneksi matematika siswa yang belajar tidak menerapkan pendekatan Realistic Mathematics Education.

\section{PENUTUP}

\section{Kesimpulan}

Berdasarkan hasil perhitungan tersebut, maka diperoleh $t_{\text {hitung }}=2,509$ dan $t_{\text {tabel }}=2,047$, dapat dikatakan bahwa $t_{\text {hitung }} \geq t_{\text {tabel }}$ atau 2,509 $\geq 2,047$ berarti Ha diterima dan $\mathrm{H}_{0}$ ditolak, hal ini bermakna bahwa ada perbedaan kemampuan koneksi matematika siswa yang belajar menerapkan pendekatan Realistic Mathematics Education dengan siswa yang belajar tidak menerapkan pendekatan Realistic Mathematics Education. Perbedaan tersebut terlihat dari perbedaan rata-rata antara kelas ekserimen dengan kelas kontrol, yakni rata-rata kelas eksperimen adalah 67,96 dan rata-rata kelas kontrol adalah 57,12.

Dengan demikian dapat disimpulkan bahwa ada pengaruh penerapan pendekatan Realistic Mathematics Education terhadap kemampuan koneksi matematika siswa di MTs Pondok Pesantren Darel Hikmah Pekanbaru. 


\section{Rekomendasi}

Berdasarkan hasil penelitian ini, peneliti memberikan rekomendasi yang berhubungan dengan Pendekatan Realistic Mathematics Education yaitu sebagai berikut:

a. Pembelajaran dengan menerapkan pendekatan Realistic Mathematics Education ini menggunakan alat peraga. Gunakan alat peraga yang sesuai dengan materi yang diajarkan. Misalnya pada materi lingkaran, alat peraga yang digunakan adalah cermin yang berbentuk lingkaran, ban mobil, kaset CD dan lain-lain.

b. Materi pada penelitian ini adalah mengenai lingkaran, lebih spesifiknya mengenai unsur, keliling dan luas lingkaran, peneliti menyarankan agar diterapkan pada materi matematika lain seperti bangun ruang, himpunan, pecahan atau materi lainnya.

c. Peneliti lain diharapkan lebih memvariasikan contoh-contoh yang nyata yang dapat mengantarkan siswa kepada kemampuan koneksi matematika siswa agar menjadi lebih baik.

d. Penelitian ini hanya difokuskan untuk melihat kemampuan koneksi matematika siswa, bagi peneliti lain yang ingin melanjutkan penelitian ini dapat meneliti objek lain dari siswa misalnya berpikir kritis, penalaran, pemecahan masalah, representatif dan sebagainya.

\section{DAFTAR PUSTAKA}

Hadi, S. (2005). Pendidikan Matematika Realistik dan Implementasinya. Banjarmasin : Tulip Banjarmasin.

Risnawati. (2008). Strategi Pembelajaran Matematika. Pekanbaru: Suska Press.

Sugiyono. (2010). Metode Penelitian Pendidikan. Bandung : Alfabeta.

Tandililing, E..Jurnal FMIPA Universitas Tanjungpura: Implementasi Realistic Mathematics Education (RME) di sekolah. Pontianak.

Tarigan, D. (2006). Pembelajaran Matematika Realistik. Jakarta: Departemen Pendidikan Nasional. 